\title{
Toward a Theory of Culturally Relevant Leadership for School-Community Culture
}

\author{
Nicole Jaenee Fraise \\ University of Georgia \\ U.S.A. \\ Jeffrey S. Brooks \\ Monash University \\ Australia
}

\begin{abstract}
The purpose of this article is to explore concepts related to culturally relevant pedagogy and connect them to nascent theoretical work in the field of educational leadership. The article begins with a review of literature on educational leadership and culture and then suggests shortcomings in the way these concepts are currently conceptualized. This is followed by a critique of literature on culturally relevant pedagogy. The article concludes with a discussion of meaningful conceptual overlap and with suggestions for further exploration and development along conceptual and empirical lines.
\end{abstract}

KEYWORDS: educational leadership, culturally relevant pedagogy, school culture, deculturalization

Educational Leadership and Culture Cultural Vantage Points

School Culture and Deculturization

Culturally Relevant Pedagogy And Culturally Relevant Leadership Conclusion

References

Author Contact

Schools have been described variously as spaces of cultural conflict where different values, beliefs, and norms create discord and as spaces of cultural cohesion where educators and students create understanding and sustain harmony (Beachum \& McCray, 2011; Horsford, 2010). Many researchers describe school and organizational culture as a mixture of these two forces in concordant opposition and argue that it is a leader's job to move a school from a negative culture toward a more positive culture (see, for example, Barth, 1990; Bolman \& Deal, 1997; Deal \& Peterson, 1991, 1999; Fullan, 2001). However, this dualistic perspective represents an oversimplified understanding of culture-and of the ways that cultures and sub-cultures interact in schools. As a result, this line of inquiry has produced few meaningful advances in research or practice, and 
more often yields little more than vacuous platitudes or vague and unsubstantiated arguments about administrators' ability to "shape" or "change" a school's culture (Brooks \& Miles, 2010). This is due in part to mistaken (implicit and explicit) assumptions as follows:

1. Schools exist as something disconnected from society. There are many studies ostensibly about culture that take nothing outside of the school into account. This has been called "doing sociology without society" in some circles.

2. Culture is a difference-blind construct, meaning that characteristics and dynamics such as race, class, gender, and sexual orientation simply do not matter or that they are somehow not part of the concept of culture (Capper, 1993; Larson \& Murtadha, 2002).

3. Cultural diversity is detrimental to the work of a school, since success is often defined as a normative construct framed through male whiteness (Young \& Laible, 2000; Scheurich \& Young, 1997).

4. There is some kind of monolithic "school culture" that means the same thing to all participants, rather than acknowledging that there are many cultures and sub-cultures flowing into and out of the school and that every individual interprets the significance of these in a unique manner (Brooks \& Normore, 2010; Brooks \& Jean-Marie, 2007).

5. Culturally relevant leadership is a general disposition rather than a paradigm of practice that also demands certain non-traditional out-ofschool behaviors that include building bridges and crossing borders between school and community (Brooks, 2009; Ladson-Billings, 1995a; Marshall \& Oliva, 2006; Merchant \& Shoho, 2006).

The twofold purpose of this article is to explore and problematize the ways that scholars conceptualize the relationship between culture and leadership and to consider alternate visions of this relationship. However, this article is meant less as critique and more as a reflection on certain key constructs and possible alternatives, focusing particularly on culturally relevant leadership (see Brooks \& Miles, 2010, for a more pointed critique of the way culture is misconceptualized in educational leadership literature). We draw primarily on research that recognizes the complexity of culture, of leadership, and of the ever-changing nature of their relationship. We are also interested in the agency of educational leaders throughout the school-community culture. We approach this work viewing leadership as a distributed phenomenon (Brooks \& Kensler, 2011; Brooks, Normore, Jean-Marie \& Hodgins, 2007; Harris, 2004; Gronn, 2002a, 2002b; Spillane, 2006) stretched over an open system that includes formal and informal educators and leaders in school, in family, and in community spheres (Habermas, 1987; Weick, 1995; Wirt \& Kirst, 1997). Our understanding of culture is informed by a thorough review of educational leadership literature and by an interdisciplinary perspective that draws primarily from sociology and cultural anthropology, though this review also led us to consider salient work in political 
science, economics, and philosophy (Bogotch, Beachum, Blount, Brooks \& English, 2008; Brooks, 2008; Brooks \& Miles, 2010; Selznick, 1984).

The article is divided into several sections. First, we draw from extant research that explains educational culture and leadership to make our perspective on the topic clear. Second, we advance some ideas already in the literature about culturally relevant leadership and add a few thoughts of our own. The central aim of this approach is to explore how leaders throughout the open educational system can use their influence and agency to help create and honor spaces where conflict and cohesion both happen, but in a manner so that they are productive and positive in terms of their educational value. The chapter ultimately challenges several accepted ways of conceptualizing the relationship between race, culture, ethnicity, and educational leadership.

We argue that "school culture" is a contrived and only partially useful construct that should be rejected, as it has traditionally led to inequitable dynamics that privilege an abstract dominant culture while marginalizing others (Ladson-Billings, 1995a, 1995b, 1995c). Instead, we suggest that several cultures and sub-cultures flow into and out of the school at all times, we draw attention to the concept of propriespect (an anthropological term for individual rather than collective culture), and we explain the importance of being aware of cultural vantage points when practicing school leadership (Brooks \& Normore, 2010; Wolcott, 1991). Further, we partially reject the notion that culture can be shaped to suit administrative purposes and suggest that schools and communities, considered as a whole, are more properly characterized as a protean constellation of individuals and groups to be understood and respected for what they can teach and learn rather than as some malleable substance that can (and should) be changed. We wonder if the widely-accepted notion that administrators should seek to change culture rather than understand and respect it is not violent and disrespectful. Forced change may result in "deculturalization," "cultural deprivation," and shaming of students' home culture in a sometimes violent clash that can be termed as "cultural collision" (Beachum \& McCray, 2011; Bejarano, 2005; Horsford, 2010; Spring, 2009). Accordingly, we argue that educators must abandon (or enter into with great caution) discussions of shaping or changing culture, discontinue melting pot and salad bowl metaphors, and instead seek to build bridges and cross borders so that the multiple cultures in the school-community can have empathy and define their own values instead of having this done by someone else.

\section{Educational Leadership and Culture}

The terms race, ethnicity, and culture are often thrown around in a cavalier manner in educational research and practice. For example, Wijeyesinghe (2001) states that "Race and racial groups refer to socially constructed concepts that divide the human population into subgroups based on real or perceived differences in such things as physical appearance or place of ancestral origin" 
(130), while Adams (2001) explains that "race in the United States has been associated with cultural, material, physical, and linguistic differences" (211). The terms race, ethnicity, and culture are ambiguous, complex, and intrinsically intertwined. Like many concepts in education, there are multiple definitions for educational culture and myriad ways leaders are taught to understand and influence culture. While this definitional ambiguity is perhaps not a problem in itself and is indeed common in the social sciences, it does mean a proliferation of research on culture and culturally-related phenomena that does not always interact or learn from one another. Put differently, researchers and practitioners are very interested in culture, but they are not always speaking or listening to each other as they develop and test their ideas. For example, educational leadership researchers have built lines of inquiry around related concepts such as organizational culture, school culture, school climate, and culturally relevant leadership and, while there is a great overlap in terms of findings and frameworks, these researchers often reinvent the wheel because their work is not informed by these other areas of inquiry (Brooks \& Miles, 2010). We are struck by how much modern theories of school culture owe to the works of Durkheim $(1893 / 1997,1897 / 1997)$, Weber $(1947,1986)$ and Whyte $(1993)$-and the many critiques of their work in the social sciences-but hardly ever see these scholars cited by educational leadership scholars (Brooks, 2006).

Racial identity is tied to cultural identity, and each group self-defines through varying processes. In New Perspectives on Racial Identity Development, Wijeyesinghe and Jackson III (2001) present eight distinct models of racial and cultural identity development. In many cases, school administration does not understand race and culture in the same manner as do the students with whom they work. The notion of cultural relativism is key in much social science research, but educational leadership scholarship is in some ways still preoccupied with the idea of a single, shared culture and is traditionally unconcerned with individual and sub-group differences. It also seems more interested in social engineering than in sociology, more in how to change culture to suit its purposes than in understanding culture (Huxley, 1932/2010). That said, there appear to be three general trends in educational leadership research on culture. The first is research that treats culture as though it is a difference-blind construct. Research of this ilk tends to describe culture as shared norms, beliefs, traditions, routines, and mores. Much of the research on culture prior to the mid1980 s assumes this perspective. Second, there is research on culture and educational leadership focused on understanding issues related to traditionally marginalized and oppressed peoples. Much of this work has focused on how educational leaders from traditionally marginalized populations become leaders and practice leadership. This research has produced quite a number of insightful findings and innovative approaches to understanding educational leadership. A third strain of educational leadership and culture research is focused on taking classic, difference-blind theories and ideas from the literature and updating/adapting/augmenting them so as to be sensitive to contemporary issues in schooling such as alienation, immigration, anomie, race, class and gender. Each of these lines of inquiry offers useful insights but, as they take into account 
a plurality of perspectives and cultures that are in today's schools, the second and third lines are much more promising than any study of culture that pretends we are all the same.

\section{Cultural Vantage Points: Paying Attention to Perspectives on Cultures}

Culture is defined in so many different ways that it would be difficult to discuss them all in this article. That said, it is still useful to point out that there are generally four distinct vantage points from which culture is viewed. Culture is often understood as the beliefs, norms, traditions, and customs of a certain group of people, with each group defining these from an insider's perspective. Thus, the first vantage point from which culture can be viewed is an emic perspective-the way that an insider makes sense of his or her culture. It is also worth noting that outsiders are simultaneously imposing their etic perspective onto sub-group activities, giving them a different meaning than what they mean to that subculture. This second vantage point, the etic perspective, is an outsider's view of sub-cultures and cultures. A third vantage point, the emic-etic perspective, seeks to reconcile the outsider and insider perspectives. This is what most ethnographers seek to do by immersing themselves in a culture. They are still outsiders, but through careful and rigorous data collection and analysis they seek to gain insights about the emic perspective, thereby merging the two. Of course, this can be done in a manner that increases cultural communication, or it can result in mistrust and a misrepresentation of the culture. The final vantage point is propriespect. Propriespect refers to the notion that every single person experiences culture differently. In a manner of speaking, this is a postmodern way of looking at culture that recognizes the unique perspective of the individual. It helps us understand, for example, how two sisters from the same family can grow up to hold very different values (Wolcott, 1991). It can also help explain how two people can interpret an event in greatly different ways (Brooks \& Normore, 2010).

It is important to note that cultural values and judgments are passed from one generation to another. That is, we pass on our values as insiders to the next generation of insiders; as outsiders, we pass on perspectives on other cultures and groups, we pass on lessons we have learned from attempts to reconcile the insider and outsider perspectives, and we also pass on our unique insights when we share perspectives and thoughts that diverge from dominant culture norms of all these groups. Importantly, this generational matriculation occurs both within schools and in boundary-spanning communities whose members are part of the school community. For example, while practices such as school traditions are passed down as students advance through the school system, so too are values around education that each student brings from their home and community. These are passed down and then evolve based on the next generation's vantage point, experience, and insights. We cannot understand the plurality of perspectives on culture that these vantage points produce-we can only seek to 
learn about difference, to honor it, and to share our perspectives with others, knowing that there is no one true culture but a rich variety of cultures (Bourdieu, 1973, 1986, 1990).

Culture is often understood as something that occurs either at home or at school, rather than as something dynamic that encompasses these two aspects of our lives as a whole. To be sure, there is a culture in the home, but there is also the culture of one's community, one's national identity, and even global communities to which we all belong, whether we are cognizant of them or not. The United States is a country that prides itself on being culturally diverse. America has been deemed the "melting pot," a place where different people from various cultures are mixed together. However, this is not what occurs in many schools. Often, students are taught that there is a dichotomy between their home culture and school culture. To some, school culture is liberating and validating, while to others it teaches them to "melt" into what is deemed as "American" and abandon their home culture (Bejarano, 2005; Spring, 2009). In conceiving of school culture as something disconnected from community culture and propriespect, administrators are melting students into a single blob of culture that in the end probably reflects no single person's perspective. In fact, what occurs in the schools is more often a process of deculturalization.

\section{School Culture and Deculturization}

Barth (1990) defines school culture as:

a complex pattern of norms, attitudes, beliefs, behaviors, values, ceremonies, traditions, and myths that are deeply ingrained in the very core of the organization. It is the historically transmitted pattern of meaning that wields astonishing power in shaping what people think and how they act. (p. 7)

If culture is generally understood as customs and beliefs and composed of traditions, practices, and behaviors, then school culture is made up of formal and informal dynamics related to espoused and hidden curricula, instructional strategies, administrator-teacher-staff-student interaction, language, communication, and policy development and implementation. It is both what happens during formal sessions in the classroom and what happens in the lunch room. But it is also about what happens at home, on the street corner, around policy makers' conference tables, and across the world. To some degree, culture is ubiquitous, stretching across school and community to create patterns and fields of meaning for individuals and groups. What occurs in some classrooms is a process of cultural collision in which the curriculum, school policies, and school culture directly collide with the culture of students. Beachum and McCray (2011) explain that school culture "communicates to students the school's attitudes toward a range of issues and problems, including how the school views them as human beings" (p. 3). This consequently results in a devaluing of some over 
others, which can be understood as cultural racism (Derman-Sparks \& Phillips, 1997). Administrators and teachers, who develop their own espoused and actual cultures and sub-cultures, influence these practices and cultural dynamics via their special formal authority in the system, a system they also participate in informally as discrete individuals.

In the United States, the staff and administration of the schools are predominantly White, which contributes to a perpetuation of a dominant hegemonic Western European school culture (see Brooks, 2012, Chapter 1 for more detailed information). In discussing school culture we must acknowledge White dominance in both the espoused and hidden curriculum and in the culture of schooling (Foucault, 1980). While many scholars have taken up this issue, Hauc (2011) argues:

The teachers in America's classrooms do not represent the student population they teach, this according to figures by the Department of Education that show that less than 15 percent of teachers in the United States are African-American or Hispanic. These figures are more alarming when taking into consideration that more than one third of America's student body, or 35 percent of them, are minorities (online).

It follows that people with the most formal authority in schools do not share the same culture of most of the students they teach. Howard (2006) also discusses the implications of the ratio of different cultures represented by the teachers and administration in his book We Can't Teach What We Don't Know: White Teachers Multiracial Schools. He states, "In this way, the educational process has allowed those in power to selectively control the flow of knowledge and inculcate into young minds only those 'truths' that solidify and perpetuate their own hegemony" (p. 54). White culture is overrepresented in the schools and is therefore the dominant culture depicted in the books and demonstrated in curriculum. Many White teachers do not acknowledge a culture of their own, further perpetuating cultural racism in the schools. White educators are often not as aware as members of minoritized cultures of the implications of the cultural practices that are perpetuated over others in the classroom and school. Howard (2006) discusses his experience as a White teacher,

[A]s whites, we usually don't even think of ourselves as having culture; we're simply 'right.' Dominant groups don't hold 'perspectives,' they hold truths. If we place this in the school context what message does this send students of color? Your view of history is just a perspective, but the history printed in your textbook is the "truth." The history of your culture is irrelevant. (p. 12)

If the teachers of the schools do not consider themselves to have a culture, then they cannot be expected to take into account the various cultures of the students sitting in their classrooms and adapt their instruction accordingly. Howard (2006) further demonstrates the importance of taking into consideration a student's home culture as he tells the story of one teacher he encountered at a multicultural workshop in Texas. The teacher expresses confusion: 
I don't understand all this talk about differences. Each of my little kindergarten students comes to me with the same stuff. It doesn't matter whether they're Black, Hispanic, or White, they each have a brain, a body, and a family. They each get the same curriculum. I treat them all alike. And yet, by the end of the year, and as I watch them move up through the grades, the Blacks and the Hispanics fall behind and the White kids do better. They all start with the same basic equipment. What Happens? (p. 24)

The fundamental problem with this discourse is the underlying assumption that all students start with the same "stuff" and that all students learn the espoused and hidden curriculum in the same manner. Of course, they don't come to school with the same cultures-they all have unique experiences and cultural vantage points. If this teacher had taken into consideration the individual culture of each student, the vantage point from which each student views the "truth" in the textbooks, and the unique perspectives her students bring to the classroom, perhaps she would not view Black and Hispanic students only as falling behind, but instead learn to value the various "truths" that her diverse students have to offer and include those truths as valuable components of the curriculum and discourse (Delpit, 1995). Perhaps she might see diversity as a spur rather than a bridle.

Many would disagree with the assertion that culture is often viewed as a deterrent in schools; after all, the United States has been deemed the "melting pot." Although the country has been deemed as the melting pot, which according to the Merriam dictionary (2012) is "a place where a variety of races, cultures, or individuals assimilate into a cohesive whole," this is not what tends to happen in our classrooms. What occurs in our classrooms is this: some students must sacrifice pieces of themselves and assimilate in order for the school to feel as though it is a "cohesive whole." Some would argue that this process of assimilation is more a process of deculturalization. Herbst (1997) states, "Deculturalization (a word newly minted in the debate over multiculturalism) is also similar in meaning to assimilation, although the idea is not so much one of absorption into another culture, but the stripping away of a person's native identity and cultural beliefs" (p. 21). Traditionally schools have intentionally and unintentionally employed cultural genocide, deculturalization, and assimilation as an approach of the varying cultures in the classrooms (Spring, 2009). Cultural genocide is the attempt to destroy a culture, while deculturalization seeks not only to destroy a culture but also to replace it with the dominant culture. Assimilation is understood as an attempt to "absorb and integrate cultures into the dominant culture" (Spring, 2009, p. 8); however, in practice this means a culture must accept the dominant culture as its own. This is evident in the use of language assimilation programs in schools, as linguistic identity is tied to cultural identity (Schecter \& Bayley, 2002). Spanish is not adapted into the English classroom, instead Spanish-speaking students are encouraged to adapt to English. In his book Deculturalization and the Struggle for Equality: A Brief History of the Education of Dominated Cultures in the United States, Spring (2009) gives an in-depth analysis of the history of deculturalization in American 
schools. Unfortunately, what Spring (2009) has termed as "history" is still a present issue in educational leadership today.

What Spring (2009) has termed as "deculturalization," Derman-Sparks and Phillips (1997) have designated as "cultural deprivation" and Beachum and McCray (2011) have named "cultural collision and collusion." Whatever the term, the end result leaves some students in the margins, while others are placed at the center. It leaves some students with a sense of value, while others feel worthless. Brown (2007) explains, "Students [are] expected to check their cultures at the school or classroom door and learn according to the norms of European Americans" (p. 61). Schools have attempted to create a homogenous culture. The creation of a homogenous school culture was implemented to help all students be viewed equally as Americans; however, it has done more harm than help. Although some schools do implement cultural pluralism, in which there is a great effort to maintain the languages and cultures of all students, this is not the case for the majority of the schools in the United States. Schools, for the most part, promote an abstracted non-culture of buzz phrases like "global learners," "all students can learn," and "success for all" that are not really cultures but promote the idea that all are one-e pluribus unum. Schools promote unity through their language, and implicitly they are driven by the melting pot metaphor. Public schools have created a model in which there is a school culture and a home culture and the two are separate entities that do not co-exist. Howard (2006) explains that "human beings tend to demonstrate discriminatory in-group and out-group dynamics even when there is an extremely limited basis for drawing distinctions between members of the groups... human beings tend to draw distinctions not only in terms of in-group and out-groups but also in terms of dominance and subordination" (pp. 32-33). Too many schools silence cultural dialogue as they promote a "school culture" and demote home culture.

\section{Culturally Relevant Pedagogy And Culturally Relevant Leadership}

However, there are other forms of leadership that value, even celebrate, culture, and build schooling around it rather than seek to change it. This is at the heart of an approach to educational called culturally relevant pedagogy, an orientation toward schooling articulated and explored initially by Ladson-Billings and her colleagues over several decades of sustained conceptual and empirical inquiry (Ladson-Billings, 1992, 1995a, 1995b, 1995c, 1997, 1998). Schools should foster a culture that takes all cultures into account with their formal and informal curricula and policies. This type of school atmosphere provides an environment in which students feel safe enough to be themselves and in which their anxiety is lowered to the point that they can concentrate on learning in a culturally safe environment. Culturally relevant pedagogy allows them to learn in the manner that best fits them, and it emphasizes several propositions that ask educators to think about and practice their work a bit differently than is typically the case (Delpit, 1995). 
First, culturally relevant pedagogy is focused on academic and nonacademic success. Banks and Banks (1995) suggest that "despite the current social inequities and hostile classroom environments, students must develop their academic skills. The way those skills are developed may vary, but all students need literacy, numeracy, technological, social and political skills" ( $p$. 160). Importantly, while academic skills are at the heart of this orientation toward education, it also makes clear that these skills must be relevant inside and outside of the classroom. Success, then, is not limited to strictly classroom success, but also to success more broadly conceived as enhanced quality of life, which also includes economic, social, and political prosperity. This means developing critical consciousness, what Paulo Freiere called conscientacao, as well as developing an aptitude for writing, reading, mathematics, and the like. A culturally relevant approach to education is essentially acculturation rather than assimilation - by this we mean that it is not about merely absorbing people into the dominant paradigm, but it is rather about the way that the (sometimes gentle and sometimes violent) clash between the dominant and subverted cultures coconstruct a new dynamic (Nieto, 2000; Sleeter, 1992).

Second, culturally relevant pedagogy demands a critical, deep, and ongoing understanding of self, other, and context as the foundation of education. This means that for education to be culturally relevant, teachers and students must begin their work together by reflecting on their own culture, values, knowledge, and situations and by seeking to understand the culture, values, knowledge, and situations of the other people with whom they will co-construct their education, and the multiple contexts in which they will learn and teach. Culturally relevant pedagogy, then, is simultaneously about learning visible curricula and unlearning hidden curricula. Students and teachers bring intentional and unintentional attitudes, dispositions, and biases to their educational practice. Therefore, it is important for us to individually and collectively engage in a process that is at once unlearning (our biases) and learning (new knowledge). Figure 1 represents a possible process of unlearning and reconstructing school leadership. The first phase of the cycle is reflection, which means reflection on both personal and collective biases and assumptions. While this is an important process for school leaders to undertake, it is perhaps even more important that they do so in public, with their peers and students. This is not only good modeling on the part of leaders but a generative and developmental activity for all. The second phase of the process is learning, which means collective inquiry on the situation at the school and in the community. It also means conducting a vigorous review of extant research on the topic in question. The purpose of the literature review is to find out what is known and unknown about the topic so as to stimulate thinking and discussion on plans of action. It is also important during this phase to take stock of school and community history to put the current issue in the proper context. Phase three is deconstruction, which entails critically looking at extant processes and outcomes and identifying whether or not they are equitable and culturally relevant. This will mean a hard and critical deconstruction of formal and informal curricula, as they exist in school and community. Reconstruction follows, wherein the community takes collective responsibility for 
establishing new norms, procedures, and processes-all toward the end of improving student learning by making what happens in the school more culturally relevant. The final stage, leadership, begins when the time to act dictates. In a sense, this is a cyclical process, and the leadership phase should loop back around to reflection-but we present it here in a linear fashion to illustrate how one cycle of the process might look.

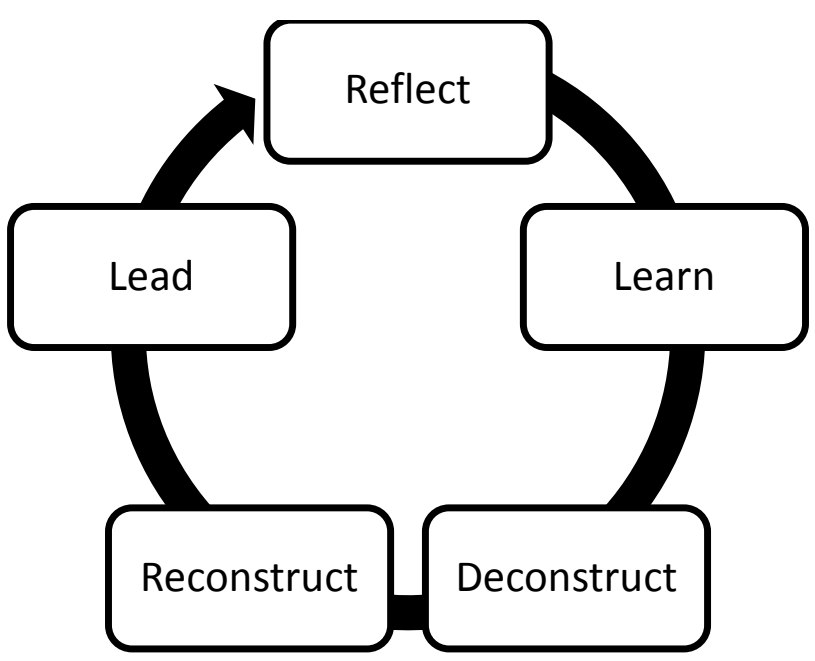

Figure 1: The Unlearning process of leadership. This figure represents a possible process of unlearning and reconstructing school leadership.

Third, culturally relevant pedagogy is a constructivist approach to education. Culturally relevant pedagogy assumes that knowledge is coconstructed by leaders, educators, students, and community members and educators as they learn together in context. This has implications for the ways that culture shapes instruction and curricula, both formally and informally. Certain instructional approaches, such as problem-based learning (Brooks, 2008) and cooperative learning (Banks \& Banks, 1995), hold more promise for promoting co-construction than didactic approaches such as lectures. Curricula should be flexible, relevant and adaptable rather than monolithic and static. They should constantly change, and they should be responsive to changes in culture, both those in the building, as well as those in the community, the nation, and the world. There is no immutable base of knowledge for the culturally relevant educator and, while there may be a core of knowledge and a base of skills that undergird the curriculum, these should constantly be challenged, updated, and changed. Put differently, this approach is about teaching with students, not at them; there is no single knowledge base, but instead multiple knowledge bases that continually evolve as new information and experiences challenge and extend existing information and experiences. Educators must build leadership, curriculum, and instruction on the foundation of student culture if they are to cocreate relevant and useful curricula (Grant, 1995). 
Fourth, culturally relevant pedagogy stresses the importance of both the immediate and long-term usefulness of education. Since culturally relevant pedagogy is founded on prior knowledge of students and teachers, it is of immediate use in that it builds on what is already there in a manner that allows students to meaningfully and progressively enhance current perspectives and knowledge. This approach also allows students to teach, educators to learn, and all to share in a culture that is community-driven rather than educator installed via an inauthentic process that includes only adults. Where is student voice in the mission and vision of the schools in which you work? What did students write that appears in the school improvement plan? Since culturally relevant pedagogy is grounded in a critical perspective toward the assimilation of that which is new and that which is old, it equips students and teachers alike with a set of skills and dispositions oriented toward lifelong learning that will serve them well long after they graduate.

\section{Conclusion}

We agree with Hollins (2011) that "an understanding of the cultural dimensions of learning is essential to effective teaching must become a key component of educational programs throughout the country" (p. xi). We believe strongly that there is a need to extend this to the study and practice of school leadership. Ultimately, for most students a school's many cultures have far more immediate influence on life and learning than the president, the state department of education, the superintendent, the school board, or even the principal, teachers, and parents can ever have (Barth 1990). Yet, it is important to keep in mind that all of these cultures flow into and out of the school and life of every student and educator. When we begin to understand and then embrace the unique culture of every student and educator, we have taken an initial step toward practicing a culturally relevant leadership. This will demand a re-thinking of the way that educational leaders are prepared and how they conceive and conduct their work in practice. This re-thinking must be based on an acceptance of the complexity of culture rather than an attempt to reduce it to a few abstract stereotypes or assumptions about people and peoples (Brooks \& Miles, 2010; Ladson-Billings, 1995a).

\section{References}

Banks, C. A. M. \& Banks, J. A. (1995). Equity pedagogy: An essential component of multicultural education. Theory Into Practice, 34(3), 152-158.

Barth, R. S. (1990). Improving schools from within: Teachers, parents, and leaders can make the difference. San Francisco, CA: Jossey-Bass Publishers. 
Beachum, F. D., \& McCray, C. R. (2011). Cultural collision and collusion: Reflections on hip-hop culture, values, and schools. New York, NY: Peter Lang Publishing.

Bogotch, I., Beachum, F. Blount, J., Brooks, J. S. \& English, F. W. (2008). Radicalizing educational leadership: Toward a theory of social justice. Amsterdam, The Netherlands: Sense Publishers.

Bejarano, C. (2005) ¿Que onda? Urban youth culture and border identity. Tucson, AZ: The University of Arizona Press.

Bolman, L. G., \& Deal, T. E. (1997). Reframing organizations: Artistry, choice, and leadership (2nd ed.). San Francisco, CA: Jossey-Bass Publishers.

Bourdieu, P. (1973). Cultural reproduction and social reproduction. In Brown Richard (Ed.), Knowledge, Education, and Cultural Change (pp. 71-112). London, UK: Tavistock.

Bourdieu, P. (1986). The forms of capital. In J. G. Richardson (Ed.), Handbook of theory and research for the sociology of education (pp. 241-258). New York, NY: Greenwood Press.

Bourdieu, P. (1990). The logic of practice (R. Nice, Trans.). Stanford, CA: Stanford University Press.

Brooks, J. S. (2012). Black school, white school: Racism and educational (mis)leadership. New York, NY: Teachers College Press.

Brooks, J. S. (2009). The miseducation of a professor of educational administration: Learning and unlearning culturally (ir)relevant leadership. In A. K. Tooms \& C. Boske (Eds.), Bridge leadership: Connecting educational leadership and social justice to improve schools (pp. 153169). Charlotte, NC: Information Age Publishing.

Brooks, J. S. (2008). Teacher alienation and burnout. In E. Provenzo (Ed.), Sage encyclopedia of social and cultural foundations in education. Thousand Oaks, CA: Sage Publications.

Brooks, J. S. (2006). The dark side of school reform: Teaching in the space between reality and utopia. Lanham, MD: Rowman \& Littlefield Education.

Brooks, J. S., Normore, A. H., Jean-Marie, G., \& Hodgins, D. (2007). Distributed leadership for social justice: Influence and equity in an urban high school. Journal of School Leadership 17(4): 378-408.

Brooks, J. S., \& Jean-Marie, G. (2007). Black leadership, white leadership: Race and race relations in an urban high school. Journal of Educational Administration, 45(6), 756-768.

Brooks, J. S. \& Kensler, L. A. W. (2011). Distributed leadership and democratic community. In F. W. English (Ed.). The SAGE Handbook of Educational Leadership: Advances in Theory, Research, and Practice (2nd Edition, pp. 55-66). Thousand Oaks, CA: SAGE. 
Brooks, J. S., \& Miles, M. T. (2010). The social and cultural dynamics of school leadership: Classic concepts and cutting-edge possibilities. In S. D. Horsford (Ed.), New perspectives in educational leadership: Exploring social, political, and community contexts and meaning (pp. 7-28). New York, NY: Peter Lang Publishing.

Brooks, J. S., \& Normore, A. H. (2010). Educational leadership and globalization: Toward a global perspective. Educational Policy, 24(1), 52-82.

Brown, M. R. (2007). Educating all students: Creating culturally responsive teachers, classrooms, and schools. Intervention in school and clinic, 43(1), 57-62.

Capper, C. A. (Ed.) (1993). Educational administration in a pluralistic society. Albany, NY: State University of New York Press.

Deal, T. E., \& Peterson, K. D. (1991). The leader's role in shaping school culture. Washington, DC: United States Department of Education.

Deal, T. E., \& Peterson, K. D. (1999). Shaping school culture: The heart of leadership. San Francisco, CA: Jossey-Bass.

Delpit, L. (1995). Other people's children: Cultural conflict in the classroom. New York, NY: New Press.

Derman-Sparks, L., \& Phillips, C. B. (1997). Teaching/learning anti-racism: A developmental approach. New York, NY: Teachers College Press.

Durkheim, E. (1893/1997). The division of labor in society. New York, NY: Free Press.

Durkheim, E. (1897/1997). Suicide. New York, NY: Free Press.

Foucault, M. (1980). Power/knowledge: Selected interviews and other writings by Michel Foucault, 1972-1977 (C. Gordon, Ed.). New York, NY: Pantheon.

Fullan, M. (2001). Leading in a culture of change. San Francisco, CA: JosseyBass.

Grant, C. A. (Ed.). (1995). Educating for diversity: An anthology of multicultural voices. Boston, MA: Allyn \& Bacon.

Gronn, P. (2002a). Distributed leadership. In K. Leithwood \& P. Hallinger (Eds.), Second international handbook of educational leadership and administration (pp. 653-696). Dordrecht, The Netherlands: Kluwer Academic Publishers.

Gronn, P. (2002b). Distributed leadership as a unit of analysis. Leadership Quarterly 13(4), 423-451.

Habermas, J. (1987). The theory of communicative action: Vol. 2. Lifeworld and system: A critique of functionalist reason (Thomas McCarthy, Trans.). Boston, MA: Beacon Press.

Harris, A. (2004). Distributed leadership and school improvement: Leading or misleading? Educational Management \& Administration, 32(1), 11-24. 
Hauc, V. (2011, March 2). Teachers of color remain a minority in US classrooms. Retrieved from http://thegrio.com/2011/03/02/teachers-of-color-remain-aminority-in-us-classrooms/

Herbst, P. (1997) The color of words: An encyclopedic dictionary of ethnic bias in the United States. Yarmouth, ME: Intercultural Press.

Hollins, E. R. (2011). The meaning of culture in learning to teach. In A. Ball \& C. Tyson (Editors). Studying diversity in teacher education. Lanham, MD: Rowman \& Littlefield.

Howard, G. R. (2006). We can't teach what we don't know: White teachers, multiracial schools. New York, NY: Teachers College Press.

Horsford, S. D. (2010). New perspectives in educational leadership: Exploring social, political, and community contexts and meaning. New York, NY: Peter Lang Publishing.

Huxley, A. (1932/2010). Brave new world. New York, NY: Harper Perennial Modern Classics.

Ladson-Billings, G. (1992). Liberatory consequences of literacy: A case of culturally relevant instruction for African American students. The Journal of Negro Education, 61(3), 378-391.

Ladson-Billings, G. J. (1995a). Toward a theory of culturally relevant pedagogy. American Education Research Journal, 32(3), 465-491.

Ladson-Billings, G. J. (1995b). Toward A critical race theory of education. Teachers College Record, 97(1), 47-68.

Ladson-Billings, G. (1995c). But that's just good teaching! The case for culturally relevant pedagogy. Theory into Practice, 34(3), 159-165.

Ladson-Billings, G. J. (1997). The dreamkeepers: Successful teachers of AfricanAmerican children. San Francisco, CA: Jossey-Bass.

Ladson-Billings, G. J. (1998). Teaching in dangerous times: Culturally relevant approaches to teacher assessment. The Journal of Negro Education, 67(3), 255-267.

Larson, C., \& Murtadha, K. (2002). Leadership for social justice, In J. Murphy (Ed.) The educational leadership challenge: Redefining leadership for the 21st century (pp. 134 -161). Chicago, IL: University of Chicago Press.

Marshall, C., \& Oliva, M. (2006). Leadership for social justice: Making revolutions in education. Boston, MA: Pearson.

Melting Pot. (2012). In Merriam-Webster.com. Retrieved November 12, 2012, from http://www.merriam-webster.com/dictionary/melting\%20pot

Merchant, B. M., \& Shoho, A. R. (2006). Bridge people: Civic and educational leaders for social justice. In Catherine Marshall and Maricela Oliva (Eds.), Leadership for social justice: Making revolutions in education (pp. 85-109). Boston, MA: Pearson Education. 
Nieto, S. (2000). Placing equity front and center: Some thoughts on transforming Teacher education for a new century. Journal of Teacher Education, 51(3), 180-187.

Schecter, S. R., Bayley, R. (2002). Language as cultural practice: Mexicanoes en el Norte. Mahwah, NJ: Lawrence Erlbaum Associates.

Scheurich, J. J., \& Young, M. D. (1997). Coloring epistemologies: Are our research epistemologies racially biased? Educational Researcher, 26(4), 4-16.

Selznick, P. (1984). Leadership in administration: A sociological interpretation. Berkeley, CA: University of California Press.

Sleeter, C. E. (1992). Keepers of the American dream: A study of staff development and multicultural education. London, UK: Falmer.

Spillane, J. P. (2006). Distributed leadership. San Francisco, CA: John Wiley.

Spring, J. (2009). American Education (14th Ed). Boston, MA: McGraw Hill.

Weber, M. (1947). The theory of social and economic organization (A.M. Henderson \& T. Parsons, Trans.). New York, NY: Oxford University Press.

Weber, M. (1986). Domination by economic power and by authority. In S. Lukes (Ed.), Power (pp. 28-36). New York, NY: New York University Press.

Weick, K. (1995). Sensemaking in organizations. Thousand Oaks, CA: Sage.

Whyte, W. F. (1993). Street corner society: The social structure of an Italian slum. Chicago, IL: University of Chicago Press.

Wirt, F. M., \& Kirst, M. W. (1997). The political dynamics of American education. Berkeley, CA: McCutchan.

Wolcott, H. F. (1991). Propriospect and the acquisition of culture. Anthropology and Education Quarterly, 22(3), 251-273.

\section{Author Contact}

Nicole Jaenee Fraise: nfraise@uga.edu

University of Georgia, Graduate School, 210 S. Jackson St. Athens, GA 30602, U.S.A.

Jeffrey S. Brooks (corresponding author): jeffrey.brooks@monash.edu Monash University, The Faculty of Education, Victoria 3800. Australia 